
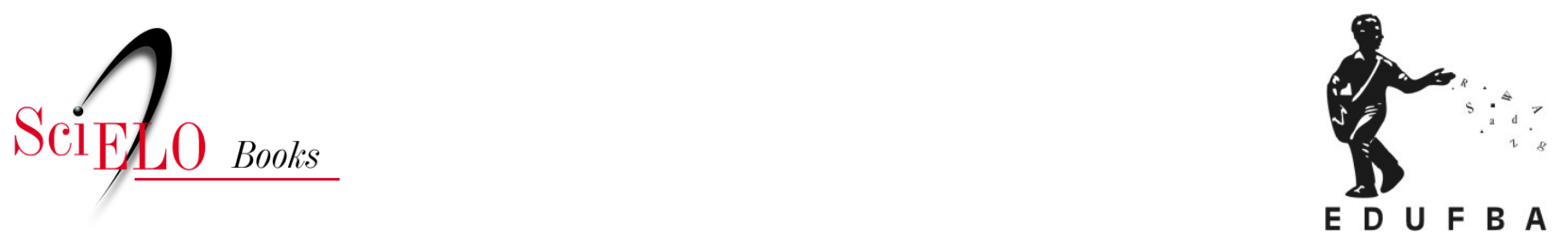

\title{
Reflexões \\ Inteligência artificial, robôs e ciência aberta
}

\author{
Nelson De Luca Pretto
}

PRETTO, N.D.L. Inteligência artificial, robôs e ciência aberta. In: Educações, culturas e hackers: escritos e reflexões [online]. Salvador: EDUFBA, 2017, pp. 147-149. ISBN: 978-85-232-2019-8. https://doi.org/10.7476/9788523220198.0034.

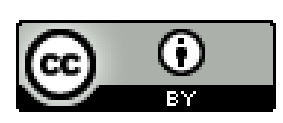

All the contents of this work, except where otherwise noted, is licensed under a Creative Commons Attribution $\underline{4.0 \text { International license. }}$

Todo o conteúdo deste trabalho, exceto quando houver ressalva, é publicado sob a licença Creative Commons Atribição 4.0.

Todo el contenido de esta obra, excepto donde se indique lo contrario, está bajo licencia de la licencia Creative Commons Reconocimento 4.0. 


\section{Inteligência artificial, robôs e ciência aberta}

Há exatos dois anos, na Campus Party de 2012, assisti uma conferência de Neil Harbisson, considerado o primeiro cyborg reconhecido oficialmente por um governo. Com uma câmera implantada em sua cabeça e computadores fazendo a conversão de cores em sons, Harbisson, que nasceu com uma doença que só lhe permitia ver tonalidades de cinza, passou a poder ouvir as cores através de um processo de interpretação do colorido dos objetos por meio das frequências sonoras recebidas de um computador implantado em seu corpo. Sua genial conferência lotou o palco principal do Anhembi, pois todos queriam entender como ele explicava esse incrível mecanismo. Lá conhecemos um pouco mais do trabalho que ele vem desenvolvendo na Fundação Cyborg, criada justamente para ajudar "as pessoas a serem cyborgs". ${ }^{33}$

Desde 1997 o Centro de Tecnologia da Informação Renato Ascher (CTI), do Ministério da Ciência e Tecnologia (em Campinas), vem pesquisando sobre a impressão de tecido humano a partir um trabalho em parceria com o cientista russo Vladimir Mironov ${ }^{34}$. Para a criação dos biomodelos necessários, o CTI desenvolveu um software, o InVesalius, licenciado de forma livre em GPL-2, hospedado e disponível para a comunidade no Portal do Software Público brasileiro. ${ }^{35}$

No ano passado, o filósofo Nick Bostrom publicou o livro Superintelligence: paths, dangers, strategies (Superinteligência: caminhos, perigos e estratégias ${ }^{36}$ ) onde apresenta resultados de pesquisa e de prospecções que indicam que os robôs vão ter, em breve, uma inteligência que superará a dos humanos. Já havíamos ouvido coisas similares pelo cientista austríaco

\footnotetext{
${ }^{33}<$ http://cyborgproject.com. Acesso em 22.02.2017>.

${ }^{34}<$ http://www.cti.gov.br/component/content/article?id=929>. Acesso em: 22 fev. 2017.

${ }^{35}<$ http://www.softwarepublico.gov.br/ver-comunidade?community_id=626732>.

${ }^{36}<$ http://en.wikipedia.org/wiki/Superintelligence:_paths,_dangers,_strategies $>$. Acesso em: 22 fev. 2017.
} 
Hans Moravec, também um especialista em Inteligência Artificial (IA) e robótica, em artigo na revista Wired, nos idos dos anos de1990 do século passado. ${ }^{37}$

Temos aqui apenas uma pequena mostra da grande revolução científica e tecnológica dos últimos 50 anos. São descobertas e inovações fruto do trabalho de milhares de pessoas, em diversas partes do mundo, seja nas universidades, nos centros de pesquisas ou em espaços não acadêmicos formais, denominados de hackerlabs ou hackerclubs, que vão transformando, de forma indelével, a maneira como vemos e vivemos o mundo contemporâneo. Essas ações podem se dar, como na maioria dos casos até agora, no interior de instituições, mesmo que públicas e que considerem a produção do conhecimento científico como algo que deva ser guardado a sete chaves, patenteado e protegido, dificultando, assim, o seu uso mais amplo e livre. No entanto, tem crescido, de forma bastante significativa, o movimento em torno da ciência aberta e cidadã que, por sua vez, articula-se com outras ações que vêm ganhando corpo na sociedade e no mundo acadêmico, em torno do acesso aberto aos dados das pesquisas, como forma de garantir a ampla circulação das informações científicas. São movimentos que têm como base a ideia de que o compartilhamento de informações é benéfico para o avanço da sociedade.

Avançam as pesquisas sobre os movimentos dos hackers, a turma assim denominada por ser apaixonada por programação de computadores. Pensar nos hackers é aguçar o olhar para os movimentos em torno do aberto, incluindo aqui as pesquisas e debates acadêmicos e políticos sobre os softwares e hardwares livres, sobre o acesso aberto às publicações científicas, os dados abertos, a governança e os parlamentos abertos, a educação aberta e, assim, pensar na possibilidade de uma mais profunda aproximação entre educação, cultura, ciência e tecnologia, implantando-se o que denominamos uma educação com um jeito hacker de ser. Essa educação hacker significa inevitavelmente caminhar na contramão daqueles que pensam em currículos únicos, bases curriculares nacionais, exames e sistemas de avaliação que tratem o diferente como o igual.

$37<$ http://archive.wired.com/wired/archive/3.10/moravec.html>. Acesso em: 26 fev. 2017. 
A tarefa não é fácil, pois todo o sistema está construído e consolidado em bases que pensam os processos de aprendizagem centrados na premissa de que se aprende do simples para o complexo, do pequeno para o grande, do perto para o distante, como se isso fosse um dado posto e que não nos coubesse discutir. Importante trazer essa discussão para a roda e, assim, com professores, gestores e alunos, todos conectados em tempo integral, pensarmos na possibilidade de transformar a escola em um rico espaço de produção de culturas e de conhecimentos, espaço poderoso para a vivência plena do universo de informação e comunicação contemporâneo. Tudo com forte ênfase em processos colaborativos, centrados na generosidade, no ativismo, com intenso protagonismo dos estudantes.

É preciso considerar essa verdadeira ação hacker, de guerrilha mesmo, como etapa fundamental para irmos muito além da escola instituída, viajando na possibilidade de trazer para nossas reflexões uma perspectiva plural que tanto nos agrada e, com isso, pensar em educações, a partir dos saberes e experiências de cada um, em cada uma de suas localidades.

Versão reduzida do título original Venha para essa guerrilha ${ }^{38}$, publicada no portal A Rede, em 4 de fevereiro de 2015

\section{Open, open, open tudo: ciência aberta}

Terminadas as festas juninas, onde comemoramos, pelo menos no Nordeste, um São João com muita animação, milho, canjica, licor e fogueira, eis que chega o mês de julho. Mês de férias para alguns, não no caso das nossas Universidades federais, em greve desde o início de junho. Mas julho é também o mês do maior evento de software livre do Brasil, o Fórum

\footnotetext{
${ }^{38}$ Disponível em: <http://www.arede.inf.br/venha-para-esta-guerrilha/>.
} 